\title{
Groundwater history and trends in Kuwait
}

\author{
E. H. AlAli \\ Kuwait Institute for Scientific Research, Kuwait
}

\begin{abstract}
In Kuwait, one of the GCC countries, natural resources of fresh water are very limited. Kuwait is situated in an arid coastal region characterized by high temperatures, low humidity, sparse precipitation rates, and high evaporation and evapotranspiration rates with no rivers or lakes. Therefore, Kuwait has always relied on other sources to secure freshwater to meet its growing demands. Groundwater quality deterioration in Kuwait is caused by two factors: one factor is the water quality in groundwater fields, where water is extracted for urban use could be affected by lateral flow of saline water. The other factor is that declining groundwater levels would accelerate the process of water quality deterioration. An alternative solution was suggested by the author to overcome the groundwater quality and quantity. A conceptual design system was introduced, consisting primarily of utilizing brackish groundwater in conjunction with treated wastewater augmentation and a reverse osmosis unit. The economical feasibility of the general conception design system was analyzed.
\end{abstract}

Keywords: Kuwait, groundwater, water level, water quality deterioration, conceptual model.

\section{Introduction}

Kuwait is an arid country with very few natural water resources (Figure 1). The only water resource in Kuwait with limited natural replenishment is groundwater. Except for some isolated fresh water lenses in northern Kuwait at Raudhatain and Umm Al-Aish, the rest of the usable groundwater is mostly saline, with some brackish zones existing in the southwestern regions. Most of the brackish groundwater fields are located in the center and western regions of Kuwait. Abdally in the north and Wafra in the south are farming areas that depend on groundwater for irrigation. The remaining groundwater in Kuwait is highly saline with a maximum of total dissolved solids (TDS) of about 200,000 
TDS. Most of the potable water comes from desalination plants (multi-stage flash distillation units) with a production cost of about $\$ 1.5-\$ 3$ per $\mathrm{m}^{3}$. Fresh water is supplied to the domestic consumer at the rate of about $\$ 0.67$ per $^{3}$ and for industrial consumers at the rate of $\$ 0.21$ per $\mathrm{m}^{3}$ (Al-Rashed et al. [2]). Supplying water at a highly subsidized price without any limitations encourages waste. Farmers are allowed to pump groundwater without any limitations, for political reasons, which has resulted in several problems, such as a large decline in water table levels and deterioration of groundwater quality, ultimately resulting in the abandonment of several farming areas.

Average annual rainfall and evapotranspiration is about $105 \mathrm{~mm}$ and 2270 $\mathrm{mm}$ respectively, so recharging of aquifers by rainfall is negligible. Low average rainfall within the region does not result in a significant direct recharge of aquifers. Extremely high evaporation rates owing to high ambient temperatures, low humidity and persistent wind action further reduce available moisture. Evaporation and transpiration produce a soil moisture deficiency that generally does not permit significant percolation or runoff to occur, except under exceptional conditions. Where surface runoff is concentrated in wadis (valley) and playa areas, there is sufficient infiltration and percolation to produce accumulations of fresh to brackish groundwater lenses. Beneath the wadis and basins where recharge occurs, the percolating water develops slight mounds of fresh to brackish water

Groundwater quality deterioration in Kuwait is caused by two factors: one factor is the water quality in groundwater fields, where water is extracted for urban use could be affected by lateral flow of saline water. The other factor is that declining groundwater levels would accelerate the process of water quality deterioration. Water quality in the field where water is extracted for irrigation is affected by return of irrigation water with a higher TDS content, and aquifer mining will allow more lateral flow of saline water.

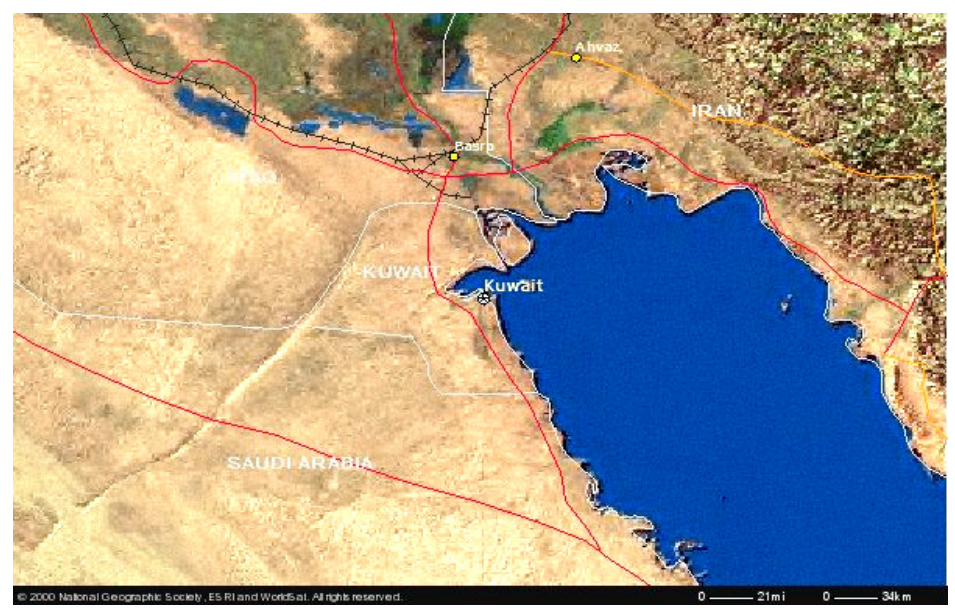

Figure 1: Aerial photo for Kuwait and neighboring countries. 


\subsection{Sources of water in Kuwait}

For fresh water in earlier days Kuwaitis depended on a few artesian wells. Dhows manned by Kuwaiti seamen also brought fresh water from the Shatt AlArab in Iraq. With the rapid growth of population, however, the government of Kuwait built the first modern desalination plant in Kuwait city in 1953, followed by others. The Doha region had two desalination plants, whose capacity reached 138 million imperial gallons per day. A third plant was set up nearby for desalination through reverse osmosis. There are three main sources of water for agricultural and urban uses; groundwater, treated wastewater and desalinated water (Akbar and Puskas [1]).

Table 1: $\quad$ Stratigraphic column section of Kuwait.

\begin{tabular}{|c|c|c|c|c|c|}
\hline Age & Group & Formation & Graphic & Lithology & Ground Water Conditions \\
\hline Recent & & & $\frac{1}{-10}$ & $\begin{array}{l}\text { Beach sands; sand; gravel; } \\
\text { playa silts and wadi } \\
\text { alluvium }\end{array}$ & $\begin{array}{l}\text { Above ground water saturation } \\
\text { or locally contain brackish to } \\
\text { saline water }\end{array}$ \\
\hline Pleistocene & \multirow{4}{*}{$\begin{array}{l}\mathrm{K} \\
\mathrm{U} \\
\mathrm{W} \\
\mathrm{A} \\
\mathrm{I} \\
\mathrm{T} \\
\\
\mathrm{G} \\
\mathbf{R} \\
0 \\
\mathrm{U} \\
\mathrm{P}\end{array}$} & \multirow[t]{2}{*}{ Dibdibba } & \multirow{2}{*}{ 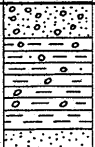 } & \multirow{2}{*}{$\begin{array}{l}\text { Coarse upland fluvial gravels } \\
\text { Gravel and sand, mainly } \\
\text { conglomeratic sandstone; } \\
\text { siltstone shale; up to } 120 \mathrm{~m}\end{array}$} & \multirow{2}{*}{$\begin{array}{l}\text { Ground water locally fresh } \\
\text { beneath wadis and depressions } \\
\text { brackish at depth }\end{array}$} \\
\hline \multirow{3}{*}{ Miocene } & & & & & \\
\hline & & Fars & $\begin{array}{ll} \\
\\
\end{array}$ & $\begin{array}{l}\text { Fine to conglomeratic } \\
\text { calcareous sandstone; sand } \\
\text { variegated shales; fossiliferous } \\
\text { limestone; gypsiferous; } 100 \mathrm{~m} \\
\text { thick }\end{array}$ & $\begin{array}{l}\text { Ground water generally } \\
\text { brackish }\end{array}$ \\
\hline & & $\begin{array}{l}\text { Undifferentiated } \\
\text { Fars and Ghar }\end{array}$ & \begin{tabular}{|l|} 
\\
0 \\
-0 \\
-1 \\
\end{tabular} & $\begin{array}{l}\text { Quartzose sandstone; sand and } \\
\text { conglomerate; some shale in } \\
\text { lower parts; few meters to } \\
250 \mathrm{~m} \text { thick }\end{array}$ & $\begin{array}{l}\text { Ground water generally } \\
\text { brackish }\end{array}$ \\
\hline \multirow{4}{*}{ Eocene } & \multirow{4}{*}{$\begin{array}{l}\mathrm{H} \\
\mathrm{A} \\
\mathrm{S} \\
\mathrm{A} \\
\\
\mathrm{G} \\
\mathrm{R} \\
\mathrm{O} \\
\mathrm{U} \\
\mathrm{P}\end{array}$} & Dammam & & $\begin{array}{l}\text { Discontinuous chert cap; } \\
\text { chalky and siliceous limestone; } \\
\text { dolomite; } 200 \mathrm{~m} \text { thick }\end{array}$ & $\begin{array}{l}\text { Moderately permeable; } \\
\text { brackish water southwest of } \\
\text { Kuwait; very brackish in east } \\
\text { and north }\end{array}$ \\
\hline & & $P$ & $11-1$ & Anhydrite; limestone; marl; & Brackish/saline ground water? \\
\hline & & Kus & & & \\
\hline & & $\begin{array}{l}\text { Umm Al- } \\
\text { Radhuma }\end{array}$ & 4 & $\begin{array}{l}\text { Marly limestone; dolomite } \\
\text { anhydrite; } 180-400 \mathrm{~m} \text { thick }\end{array}$ & Brackish/saline ground water? \\
\hline
\end{tabular}

\subsection{Topography and geology of Kuwait}

\subsubsection{Kuwait group}

The Kuwait group underlies the unconsolidated recent and sub- recent sediments of various types, ranging from gravels and sand to fine grained coastal deposits, sandstone, clay, silts and limestone or marls covering the entire surface of Kuwait. Additionally, it extends down to the top of the underlying Dammam limestone formation. The stratigraphic sequence consists of sediments ranging in age from Miocene to Holocene. It includes conglomerates, sandstones, sandy limestones, clay stones, sand and gravel. Kuwait group aquifer was subdivided, in north Kuwait, into three formations based on the presence of intermediate evaporite deposits as follows: 
1. Dibdibba Formation

2. Fars Formation

3. Ghar Formation
Sand and Gravel

Evaporite Sequences

sand and Gravels

The thickness of the Kuwait Group increases from about $150 \mathrm{~m}$ in the southwest to about $400 \mathrm{~m}$ in the northeast. The Kuwait Group is completely dry in the extreme southwest, and is almost saturated with water along the coast of the Arabian Gulf. Due to the absence of the Fars formation, the Kuwait Group is undifferentiated in southern Kuwait.

\subsubsection{Hydrostratigraphy}

The clastic sequence of the Kuwait Group is hydrologically heterogeneous due to the uneven distribution of the clay lenses and variation in the degree of cementation both laterally and vertically. Lithological and geophysical studies show three recognizable zones of reduced hydraulic conductivity, caused by the preponderance of clayey ranges that can be correlated over large distances. Hence, these three zones act as aquitards and divide the Kuwait Group into three recognizable aquifer units. These aquitards and the aquifer sequence within the Kuwait Group, from top to bottom, are as follows:

\begin{tabular}{|ll|}
\hline - & Dibdibba Aquifer (gravel sand). \\
\hline - & Aquitard (silty sand). \\
\hline - & Upper Kuwait Group Aquifer (sand and gravel). \\
\hline - & Aquitard (clay and clay sand). \\
\hline - & Lower Kuwait Group Aquifer (sand). \\
\hline - & Aquitard (basal clay and cherty limestone at the top of \\
& Dammam formation). \\
\hline
\end{tabular}

\subsubsection{Potentiometry}

All the subdivisions of the Kuwait Group, aquifers and aquitards, are connected with one another and with the underlying Dammam Formation. The regional potentiometric gradient is from southwest to northeast. Within the state of Kuwait, the Kuwait Group gains its water from the lateral inflow from Saudi Arabia and from the Dammam limestone through upward leakage (Figure 2). The potentiometric head generally increases with depth giving rise to the upward component of the flow. The mean value of the head, however, decreases toward the northeast and east direction, toward the area of discharge, toward Kuwait Bay to be discharged by evapotranspiration at the marsh lands along the shoreline and ultimately into the bay and gulf by seepage. The piezometric head of the Kuwait Group indicates that water levels were about 120 a.m.s.l. in the southwestern corner of Kuwait (Al-Ruwaih et al. [3]).

\section{Problem identification}

In Kuwait, one of the GCC countries, natural resources of fresh water are very limited. Kuwait is situated in an arid coastal region characterized by high 
temperatures, low humidity, sparse precipitation rates, and high evaporation and evapotranspiration rates with no rivers or lakes. Therefore, Kuwait has always relied on other sources to secure freshwater to meet its growing demands. The water supply in Kuwait can be obtained from three main sources: brackish groundwater, water reuse (treated wastewater), and seawater desalination. There are three classes of groundwater in Kuwait: fresh water with salinity below 1000 ppm, which is used for drinking and domestic purposes, slightly saline water with salinity ranging between 1000 and $10000 \mathrm{ppm}$, which is used for irrigation, and highly saline water with salinity exceeding $10000 \mathrm{ppm}$. In general, groundwater quality and quantity are deteriorating due to the continuous mining of groundwater. On the Al-Wafra farms, in the south, $50 \%$ of the wells pumped water with a salinity level higher than 7,500 ppm in 1989 (Figures 3 and 4).

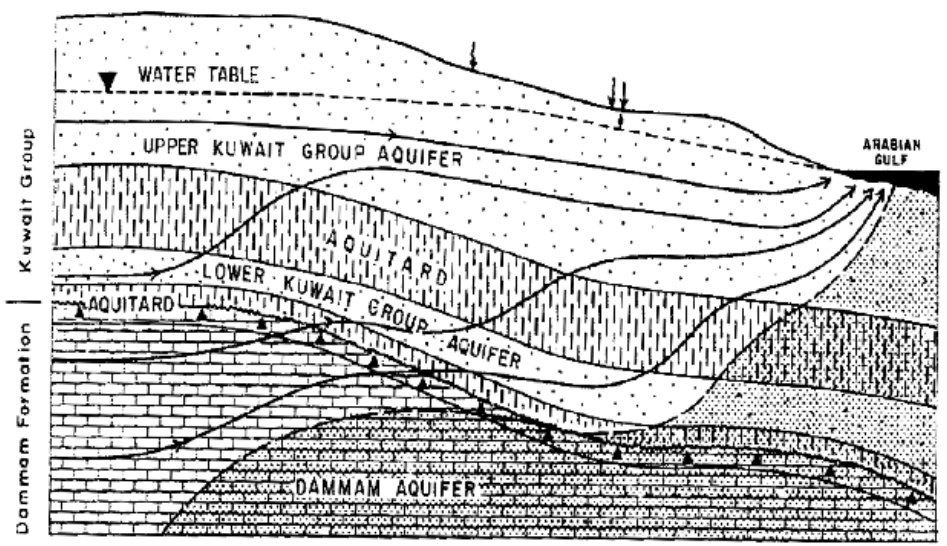

\begin{tabular}{|c|c|c|}
\hline SAND & 泪困 & SILT \& CLAY \\
\hline LIMESTONE & $E$ & CHERTY LIMESTONE \\
\hline SALINE STAGNANT WATER & $\Rightarrow$ & GROUNO WATER FLOWLINE \\
\hline
\end{tabular}

Figure 2: $\quad$ Schematic model of the groundwater flow system in Kuwait.

This figure reached to $75-80 \%$ and $85-90 \%$ in the years 1997 and 2003 respectively. On the Al-Abdally farms, in the north, $55 \%$ of the deep drilled 


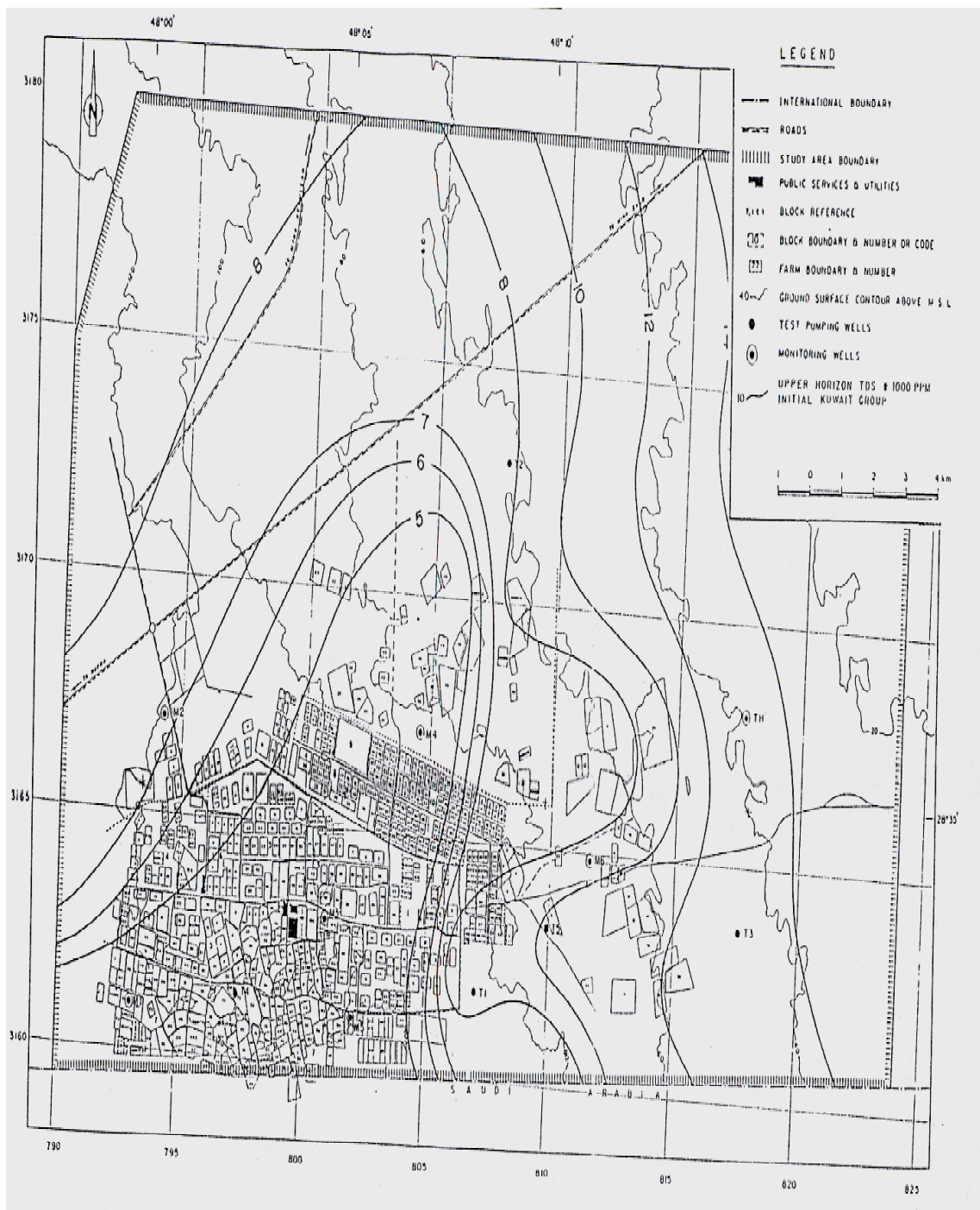

Figure 3: TDS contours of the Wafra farms - Kuwait Group 1993 - upper horizon, (ppm x100), (Al-Rashed et al. [2]).

wells pumped water with a salinity level higher than 7,500 ppm in 1989 . This reached to $75 \%$ and $90 \%$ after 5 and 10 years of operation respectively.

Brackish groundwater exists in reasonable quantities. During 1999, the daily production of brackish groundwater was around 400 million imperial gallons per day (MIGD), which is almost 3 times the annual groundwater inflow (MEW, 2000 [5]). Thus, the production of brackish groundwater is exhausting the one and only vital natural water source. What is more, there are no water charges or limits on groundwater use by farmers. Additionally, brackish groundwater 


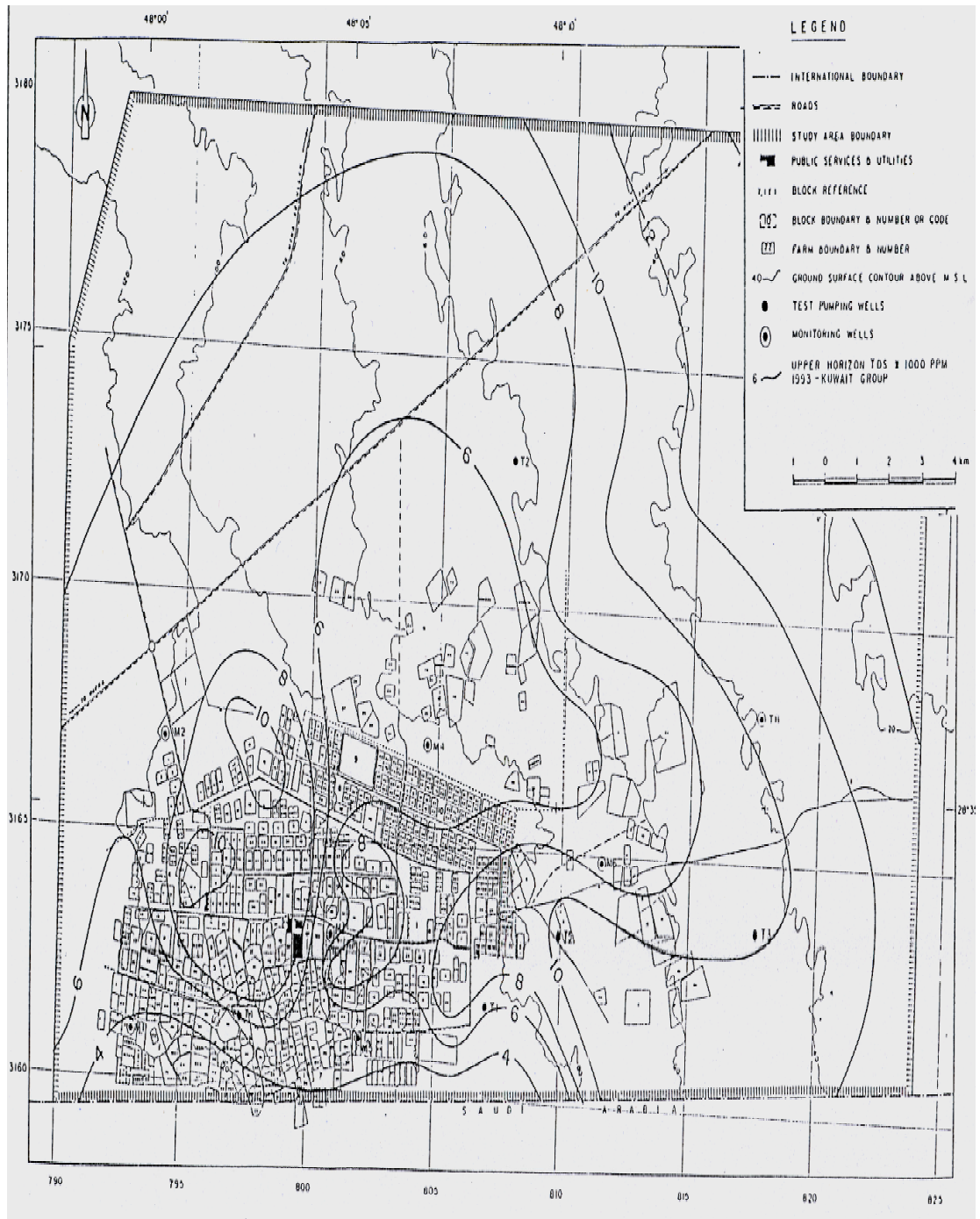

Figure 4: TDS contours of the Wafra farms - Kuwait Group 1999 - upper horizon (ppm x100), (Al-Rashed et al. [2]).

mining will have severe and serious consequences on the quality and quantity of scatters lenses of brackish water in the future due to saltwater intrusion of more saline (brine) surrounding water (Figures 5 and 6).

\section{Methodology and trends}

The utilization of unconventional water sources may be one of the vital solutions to over come the groundwater quality and quantity deterioration, in specific, the 
160 Sustainable Irrigation Management, Technologies and Policies II

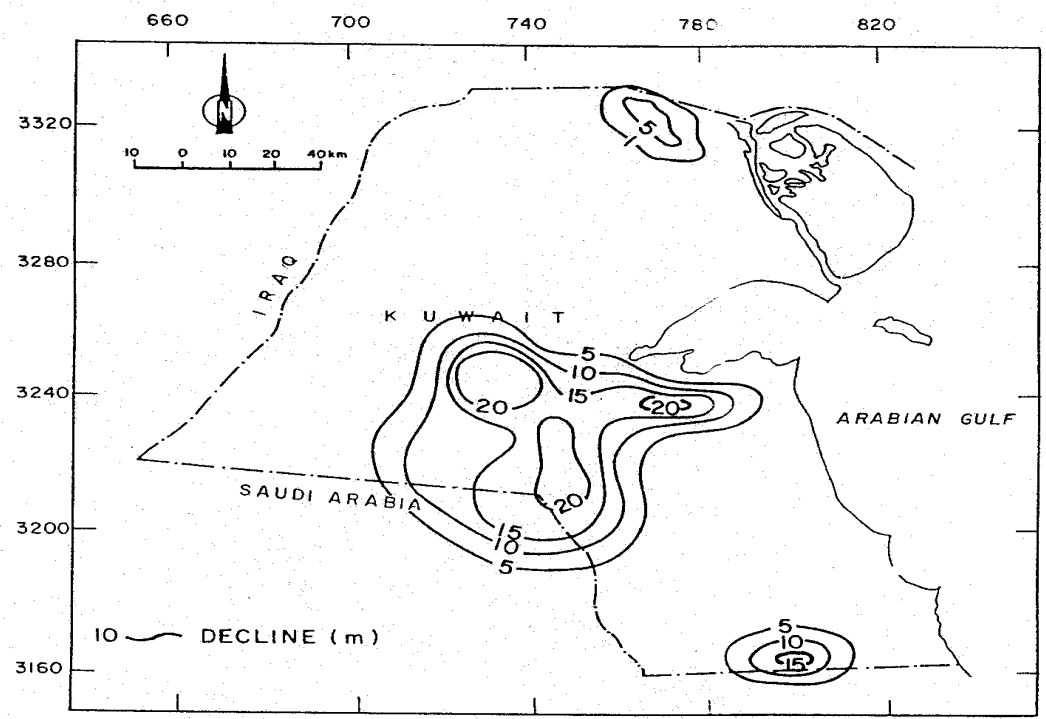

Figure 5: Depletion of groundwater levels: the Kuwait Group 1960-90, (AlRashed et al. [2]).

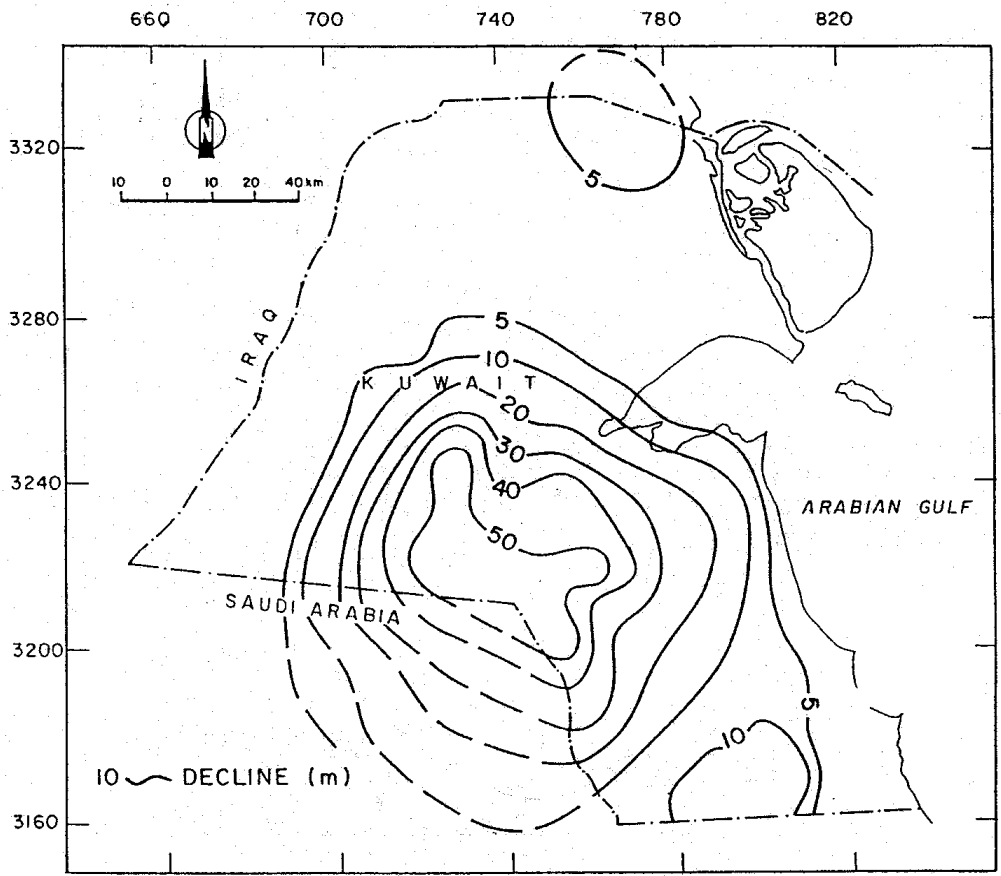

Figure 6: Predicted decline in groundwater levels: the Kuwait Group 2010, (Al-Rashed et al. [2]). 
initiations of effective steps to reduce the rate of declining groundwater levels would also reduce the risk of groundwater deterioration. In Kuwait, treated wastewater is an almost unused water source. Urban wastewater is collected, treated and returned to the sea; limited quantities are utilized for landscaping purposes. In Kuwait, wastewater effluent is treated to a secondary or tertiary level. The relatively low salinity of the treated wastewater $(1000 \mathrm{mg} / \mathrm{l})$ compared with brackish groundwater of 4000-10000 mg/l makes it a potentially excellent source of good quality water. Moreover, over 100 million imperial gallons per day (MIGD) of treated wastewater production in Kuwait will have a great potential to supplement/ replace the brackish groundwater supplies, hence, by either direct application and utilization for agricultural and urban usage or by the method of augmenting the groundwater by mean of injection process, thus, reducing the burden on groundwater mining and stabilizing and enhancing the groundwater quality and quantity in the long run for the agricultural and urban sector utilization.

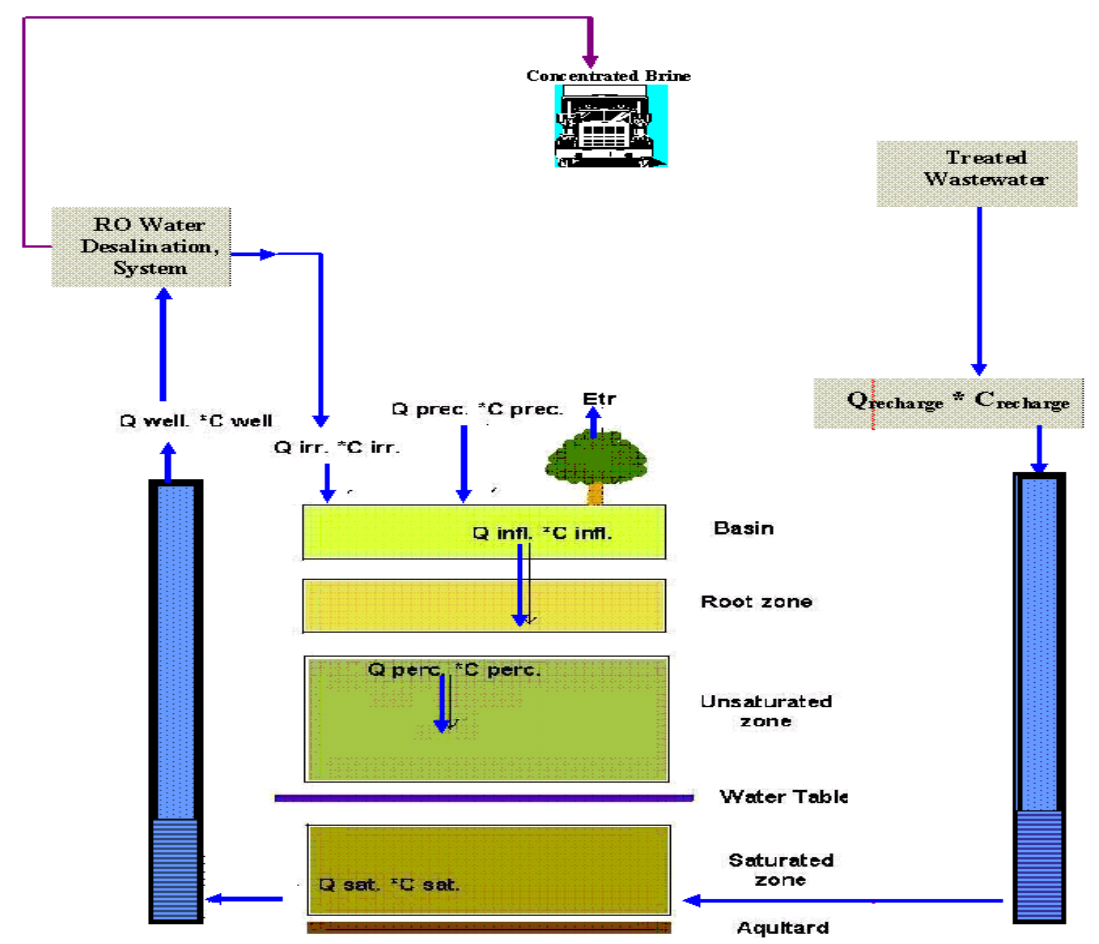

Figure 7: Conceptual design system of implementing a treated wastewater recharge technique and R.O. unit system for water sustainability.

The author conducted a study utilizing a conceptual design model system utilizing brackish groundwater in conjunction with treated wastewater augmentation and a reverse osmosis unit to achieve water sustainability (Figure 
7) for the agricultural utilization . The study will result in achieving a sustainable water strategy (quantity and quality) and the relief and restoration of the aquifer after years of human over mining and uneconomical practices of brackish groundwater utilization for urban agricultural purposes.

The study employed two approaches, the lump model approach and the areal distribution model approach. The lump model approach was carried out through the construction of a simplified model approach utilizing the Visual Basic model. On the other hand, the areal distribution model approach was carried out through the utilization of the Visual MODFLOW and MT3D simulation model approach. The economical feasibility of the general conception design system was analyzed for the lump model simulation approach and for the three orientation layouts of the areal distribution model approach. The economical analysis was based on the calculations of the net present worth value of the cash flows for the capital cost, the operation and maintenance costs, and the revenues of the crop yields for the 40 years of operation. The benefit-cost ratios for the base case of the general conceptual design system using the lump model approach and the areal distribution model for the three orientation layouts were calculated for ranges of different interest rates $(2 \%, 4 \%, 6 \%$ and $8 \%)$.

\section{Results and conclusion}

From Figures 8 and 9, the benefit-cost ratios for all the simulation approaches methods were less than 1 , except for the condition at interest rate of $2 \%$. As an

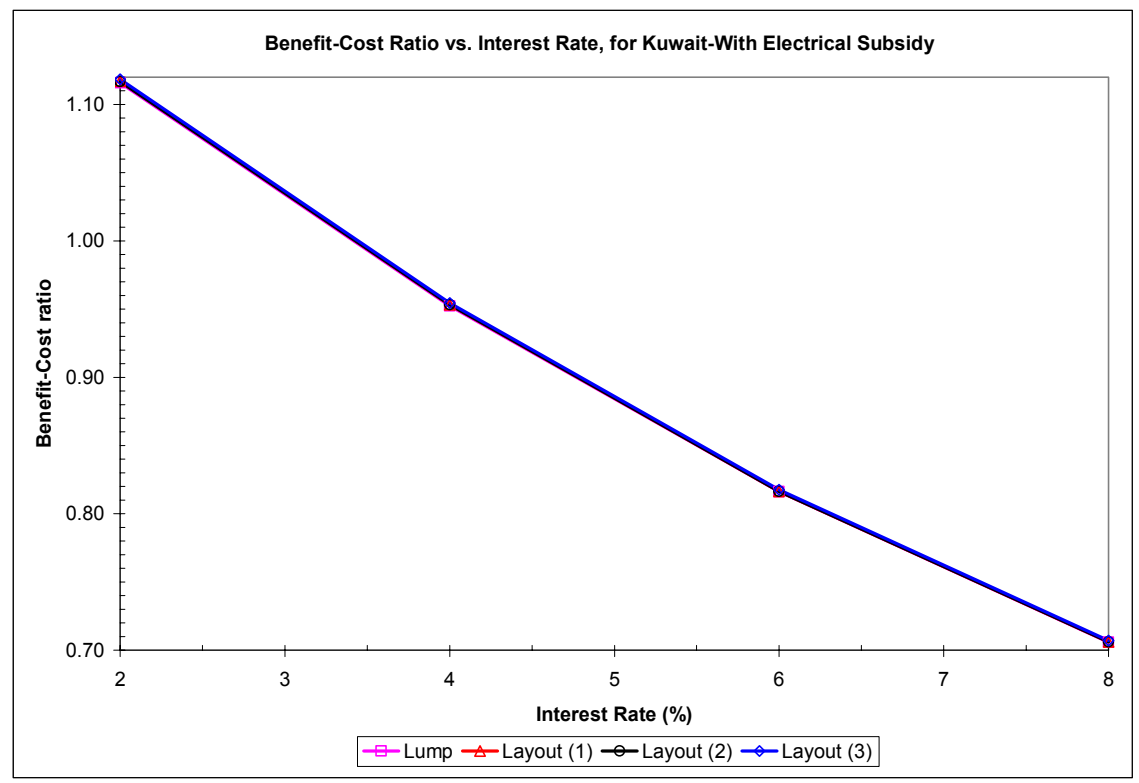

Figure 8: Benefit-Cost ratios for ranges of different interest rates for Kuwait for with electrical subsidy. 


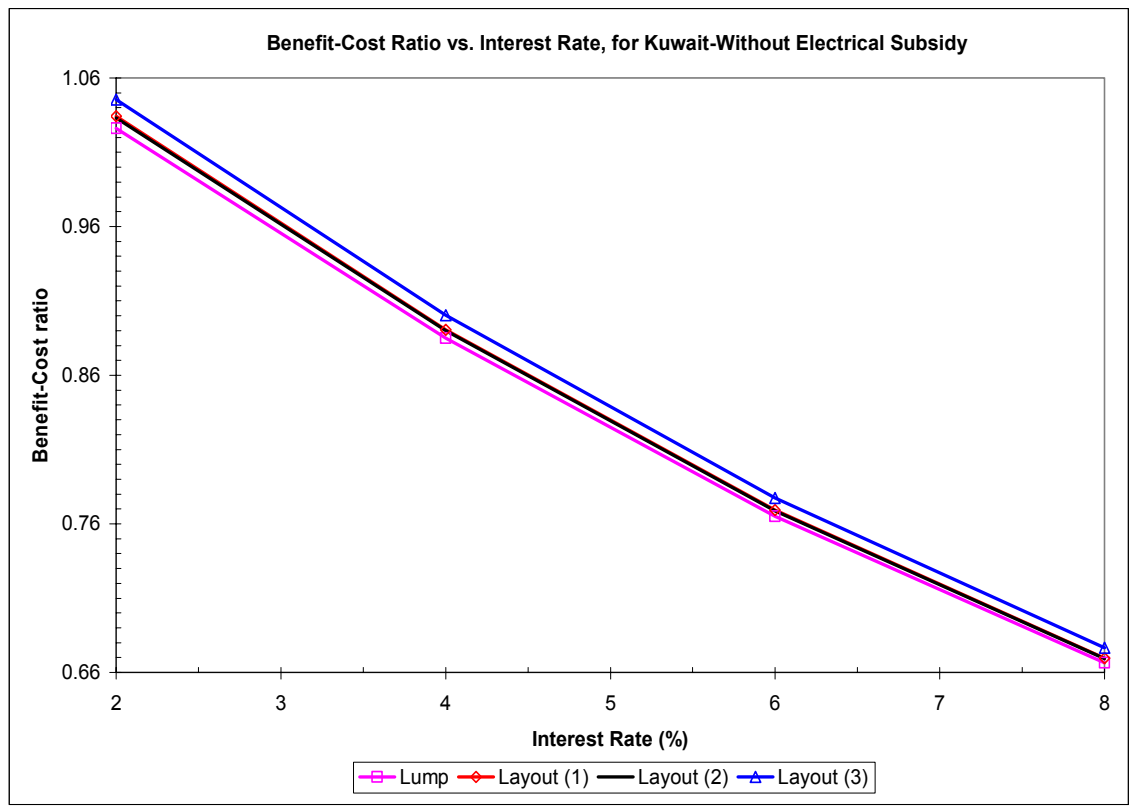

Figure 9: Benefit-Cost ratios for ranges of different interest rates for Kuwait without electrical subsidy.

initial conclusion, from the benefit-cost ratio results, the general conceptual design system is unfeasible for most of the simulation method approaches when the interest rate is higher than $2 \%$. For Kuwait, specifically, and the GCC, in general, food-self efficiency is one of the main aspects of the government's higher political strategy. For that reason, oil wealth is used as a highly valuable commodity traded for food. Furthermore, the GCC countries, as an example, provide long period loans (up to 50 years) with $2 \%$ interest rates for small to medium size projects (Industrial Bank of Kuwait) to create more job and work activities for small investors, thus, helping to reduce the unemployment phenomena and create more job opportunities. In addition, the GCC governments adapted a strong trend in encouraging the establishment of private sectors, which in return, will help provide more job opportunities, where $90 \%$ of the GCC citizens are now employed by the government. Therefore, this will reduce the burden from the government shoulders. Thus, the general conceptual design model can be strongly economically feasible, especially with the $2 \%$ interest rate and electrical power subsidy, where the benefit-cost ratio $=1.1184$.

\section{References}

[1] Akbar, A., and K. Puskas (1992). Water Availability. Sub-task 2b. In Development Study for the Agricultural Sector in Kuwait. Progress Report. Kuwait Institute for Scientific Research. 
164 Sustainable Irrigation Management, Technologies and Policies II

[2] Al-Rashed, M., M.N. Al-Senafy, M.N. Viswanathan, and A. Sumait (1998). Groundwater Utilization in Kuwait: Some Problems and Solutions. Water Resource Development, Vol 14, N0. 1, pp. 91-105.

[3] Al-Ruwaih, F.M., S. Sayed, and M. Al-Rashed (1998). Geological Controls on Water Quality in Arid Kuwait. Journal of Arid Environments, Vol. 38, pp. 187-204.

[4] Darwish, M.A., and A.M. Jawad (1989a). Technical comparison between large capacity MSF and RO desalting plants. Proceedings of the Fourth World Congress on Desalination and Water Reuse, Kuwait. International Desalination Association. Desalination 76 (4): 281-304.

[5] MEW (2000). Water Statistical Year Book. Ministry of Electricity and Water, Kuwait. 